\title{
Penurunan Aktivitas Fisik dan Peningkatan Status Gizi Selama Pandemi Covid-19 Pada Mahasiswa Olahraga
}

\section{Decrease in Physical Activity and Improved Nutritional Status During The Covid-19 Pandemic in Sports Students}

\author{
Arifah Kaharina ${ }^{1}$, Idzam Kholid Akbar², Oce Wiriawan³, Hari Setijono4 \\ 1,2,4Fakultas IImu Olahraga, Universitas Negeri Surabaya, Indonesia \\ ${ }^{3}$ Achilles Sport Science and Fitness Center, Universitas Negeri Surabaya, Indonesia \\ email: arifahkaharina@unesa.ac.id 1 \\ do \\ : https://doi.org/10.20884/1.paju.2021.3.1.4559
}

\begin{abstract}
Abstrak
Covid-19 telah ditetapkan sebagai kondisi darurat kesehatan masyarakat internasional. Pemberlakuan physical distancing mengharuskan untuk mengurangi mobilitas dan menuntut perubahan secara drastis. Mahasiswa yang harus menghentikan proses pembelajaran secara luring menjadi salah satu kelompok yang terkena dampak, baik dari kesehatan fisik dan mental. Penelitian ini bertujuan untuk mengetahui perubahan pola aktivitas fisik dan status gizi sebelum dan selama pandemi covid-19 pada mahasiswa olahraga. Penelitian menggunakan metode kuantitatif dengan desain penelitian survey. Subjek penelitian ini sebanyak 117 mahasiswa olahraga bukan atlet profesional mengisi angket penelitian berupa pengukuran antropometri dan aktivitas fisik menggunakan kuesioner IPAQ. Data hasil penelitian dianalisis dengan menggunakan perhitungan uji beda Mann Whitney. Terdapat penurunan yang signifikan pada aktivitas fisik $(p=0.000)$ dan peningkatan yang signifikan pada status gizi yang dilihat dari nilai IMT $(p=0.000)$. Penurunan aktivitas fisik dan perilaku sedenter yang berkepanjangan meningkatkan akumulasi lemak sehingga dapat berakibat pada peningkatan berat badan dan risiko obesitas. Diperlukan pemahaman tentang penerapan pola aktivitas fisik yang tepat yang dapat dilakukan selama physical distancing dan pemantauan kondisi fisik secara berkala untuk dapat mempertahankan imunitas tubuh. Kesimpulan dari penelitian ini physical distancing selama satu tahun berdampak penurunan aktivitas fisik dan peningkatan IMT secara signifikan pada mahasiswa olahraga.
\end{abstract}

Kata Kunci: Aktivitas Fisik, Covid-19, Pandemi, Status Gizi

\begin{abstract}
Covid-19 has been declared an international public health emergency. The implementation of physical distancing requires reducing mobility and demands drastic changes. Students have to stop the offline learning process are one of the groups affected, both physically and mentally. The research aims to determine changes in physical activity patterns and nutritional status before and during the
\end{abstract}


covid-19 pandemic in sports students. The research uses quantitative methods with a survey research design. The subjects of this study were 117 nonprofessional sports students who filled out research questionnaires in the form of anthropometric measurements and physical activity using the IPAQ questionnaire. The research data were analyzed by using the calculation of the Mann Whitney difference test. There was a significant decrease in physical activity $(p=0.000)$ and a significant increase in nutritional status as seen from the $B M I$ value $(p=0.000)$. Decreased physical activity and prolonged sedentary behavior increase fat accumulation so that it can result in increased body weight and the risk of obesity. An understanding of the application of appropriate physical activity patterns that can be carried out during physical distancing and regular monitoring of physical conditions is needed to be able to maintain body immunity. This study concludes that physical distancing for one year has an impact on decreasing physical activity and increasing BMI significantly in sports students.

Keywords: Covid-19, Nutritional Status, Pandemic, Physical Activity

\section{PENDAHULUAN}

Penyebaran Coronavirus Desease 2019 (Covid-19) yang masih berlangsung menjadi situasi darurat kesehatan masyarakat dan ancaman global. Berbagai upaya dalam menangani lonjakan kasus yang kian meningkat telah dilakukan, seperti penerapan kebiasaan baru, Pembatasan Sosial Berskala Besar (PSBB), hingga Pemberlakuan Pembatasan Kegiatan Pasyarakat (PPKM). Upaya physical distancing tersebut mengharuskan masyarakat untuk membatasi mobilitas dan aktivitas diluar rumah, sehingga berlaku juga sekolah secara daring bagi siswa maupun mahasiswa. Hal ini berarti siswa maupun mahasiswa yang biasanya belajar dengan datang secara langsung ke sekolah maupun kampus dan melakukan aktivitas fisik secara tidak langsung, akan cenderung hanya berdiam diri didepan layar gawai maupun laptop (Rojali, et al., 2021). Dampak pembatasan tersebut dirasakan anak-anak dan remaja berkaitan dengan masalah kesehatan dan mental harus menjadi perhatian.

Perilaku gaya hidup anak-anak dan remaja, seperti aktivitas fisik dan perilaku sedenter mungkin terpengaruh secara drastis karena penutupan sekolah yang berkepanjangan dan aturan pembatasan mobilitas selama pandemi (UNESCO, 2020). Studi menunjukkan penurunan aktivitas fisik dan perilaku sedenter yang berkepanjangan berhubungan dengan hasil kesehatan fisik dan mental yang buruk (Jiménez-Pavón, Carbonell-Baeza, \& Lavie, 2020). Bukti menunjukkan bahwa dampak negatifnya dapat berlanjut hingga dewasa (WHO, 2010). 
Arifah Kaharina, Idzam Kholid Akbar, Oce Wiriawan \& Hari Setijono | Penurunan Aktivitas Fisik dan Peningkatan Status Gizi Selama Pandemi Covid-19 Pada Mahasiswa Olahraga

Menjadi penting untuk selalu memantau status gizi secara berkala sebagai salah satu indikator dari kesehatan tubuh. Terlebih saat pandemi seperti sekarang ini, kesehatan harus menjadi perhatian utama agar imunitas tubuh selalu terjaga. Pembatasan sosial yang dijalani akan meningkatkan perilaku sedenter sekaligus penurunan aktivitas fisik, sehingga menyebabkan peningkatan akumulasi lemak (Nogueira-de-Almeida et al., 2020). Akumulasi lemak akan berakibat salah satunya pada peningkatan berat badan dan dalam jangka waktu tertentu dapat meningkatkan risiko obesitas dan berbagai penyakit tidak menular lain.

Penurunan aktivitas fisik dan perilaku sedenter tidak hanya berdampak negatif terhadap kesehatan fisik dan mental, namun juga dilaporkan terjadi penurunan prestasi akademik (Haapala et al., 2017). Diperlukan pemahaman tentang penerapan pola aktivitas fisik yang tepat yang dapat dilakukan selama pembatasan sosial dan pemantauan kondisi fisik secara berkala agar terhindar dari perilaku sedenter dan status gizi berlebih. Mahasiswa olahraga dituntut memiliki kondisi fisik yang prima untuk mendukung aktivitas pembelajaran yang sebagian besar dalam bentuk praktik. Sehingga pemahaman yang lebih baik tentang situasi ini di kalangan mahasiswa olahraga menjadi penting untuk diketahui. Namun masih terbatasnya penelitian berkaitan dengan hal tersebut, sehingga peneliti ingin mengetahui seberapa besar perubahan pola aktivitas fisik dan status gizi mahasiswa ilmu olahraga selama menjalani pembatasan sosial selama satu tahun sejak ditetapkannya Covid-19 sebagai pandemi global.

\section{METODE}

Penelitian ini menggunakan metode kuantitatif dengan desain penelitian survey. Pemilihan subjek penelitian menggunakan purposive sampling (Sugiyono, 2019). Kriteria pemilihan sampel yaitu: (1) mahasiswa aktif Fakultas IImu Olahraga Universitas Negeri Surabaya yang telah menempuh minimal 2 semester perkuliahan; (2) berstatus bukan atlet profesional dan tidak menjalani latihan yang terprogram dari pelatih/klub; (3) tidak dalam keadaan sakit dalam waktu seminggu sebelum pengisian angket. Responden penelitian ini sebanyak 117 mahasiswa terdiri dari 85 laki-laki dan 32 perempuan yang mengisi angket penelitian berupa pengukuran antropometri dan aktivitas fisik. Pengambilan data dilakukan sebelum pandemi dan selama pandemi telah berlangsung selama satu tahun (tepatnya bulan Maret 2021). 
Data antropometri diambil dengan mengukur tinggi badan dan berat badan subjek. Melalui penghitungan, didapat data IMT dengan kategori dapat dilihat pada tabel 1.

Table 1. Kategori IMT (Kemenkes RI, 2018)

\begin{tabular}{lc}
\hline \multicolumn{1}{c}{ Kategori } & IMT \\
\hline Gemuk Berat & $>27$ \\
\hline Gemuk Ringan & $25.1-27.00$ \\
\hline Normal & $18.5-25.00$ \\
\hline Kurus Ringan & $17.00-18.40$ \\
\hline Kurus Berat & $<17.00$ \\
\hline
\end{tabular}

Aktivitas fisik diukur menggunakan International Physical Activity Questionnaire (IPAQ) (Fogelholm et al., 2006). Skor aktivitas fisik didapat dari nilai METs-menit/minggu yang merupakan penjumlahan dari aktivitas berjalan, aktivitas sedang, dan aktivitas berat dalam durasi (menit) dan frekuensi (hari), yang kemudian dikalikan dengan nilai masingmasing METs. Level aktivitas fisik dapat ditentukan melalui tabel 2.

Table 2. Kategori level aktivitas fisik menggunakan instrumen IPAQ

\begin{tabular}{lc}
\hline \multicolumn{1}{c}{ Kategori } & Nilai METs (menit/minggu) \\
\hline Berat & $>3000$ \\
\hline Sedang & $600-3000$ \\
\hline Rendah & $<600$ \\
\hline
\end{tabular}

Data yang diperoleh dianalisis dan dilakukan uji beda Mann Whitney. Data yang diuji data non-parametrik karena data tersebut tidak berdistribusi normal sehingga analisis uji beda menggunakan Mann Whitney.

HASIL

Berikut merupakan hasil pengambilan data, dimana keadaan selama pandemi telah berlangsung selama 1 tahun semenjak Covid-19 ditetapkan sebagai pandemi global. Karakteristik subjek penelitian yang memenuhi kriteria inklusi dapat dilihat pada tabel 3 dibawah ini:

Tabel 3. Karakteristik subjek penelitian

\begin{tabular}{lcccc}
\hline \multicolumn{1}{c}{ Karakteristik } & N & Min & Maks & Rata-rata \pm SD \\
\hline Umur (tahun) & 117 & 18 & 22 & $19.04 \pm 0.66$ \\
\hline Tinggi Badan $(\mathrm{cm})$ & 117 & 150 & 185 & $166.41 \pm 7.69$ \\
\hline
\end{tabular}


Arifah Kaharina, Idzam Kholid Akbar, Oce Wiriawan \& Hari Setijono | Penurunan Aktivitas Fisik dan Peningkatan Status Gizi Selama Pandemi Covid-19 Pada Mahasiswa Olahraga

\begin{tabular}{lllll}
\hline Berat Badan (kg) & 117 & 41 & 98 & $61.77 \pm 10.95$
\end{tabular}

Berdasarkan tabel tersebut, karateristik subjek penelitian dengan rentang umur 11 sampai 22 tahun yang terdiri dari 75 mahasiswa laki-laki dan 32 mahasiswa perempuan. Berikut nilai IMT dan aktivitas fisik subjek sebelum dan selama pandemi Covid-19 dapat dilihat pada tabel 4 dibawah ini:

Tabel 4. Nilai IMT dan aktivitas fisik sebelum dan selama pandemi

\begin{tabular}{lcccc}
\hline \multicolumn{1}{c}{ Variabel } & $\begin{array}{c}\text { Sebelum Pandemi } \\
(\text { Mean } \pm \text { SD })\end{array}$ & $\begin{array}{c}\text { Selama Pandemi } \\
(\text { Mean } \pm \text { SD })\end{array}$ & $\begin{array}{c}\text { Delta } \\
(\text { Mean } \pm \text { SD })\end{array}$ & Nilai $\boldsymbol{p}$ \\
\hline $\begin{array}{l}\text { Aktivitas Fisik (MET- } \\
\text { menit/minggu) }\end{array}$ & $4330.20 \pm 2701.66$ & $2595.50 \pm 2330.58$ & $-1734.70 \pm 1226.06$ & $0.000^{*}$ \\
\hline IMT $\left(\mathrm{kg} / \mathrm{m}^{2}\right)$ & $21.91 \pm 2.90$ & $22.20 \pm 2.83$ & $0.29 \pm 0.80$ & $0.000^{*}$ \\
\hline
\end{tabular}

${ }^{*}$ berbeda signifikan sebelum dan selama pandemi $(p<0.05)$

Berdasarkan uji beda tabel 4 diketahui semua variabel menunjukkan hasil yang signifikan $(p<0.05)$, hal ini berarti seluruh variabel pada keadaan sebelum pandemi dan selama pandemi berbeda secara signifikan.

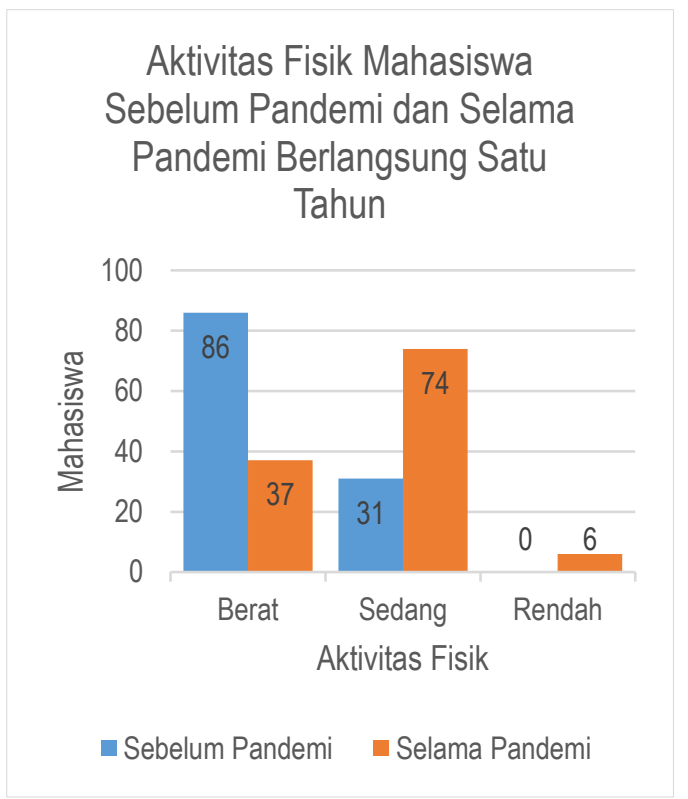

Gambar 1. Grafik Aktivitas Fisik

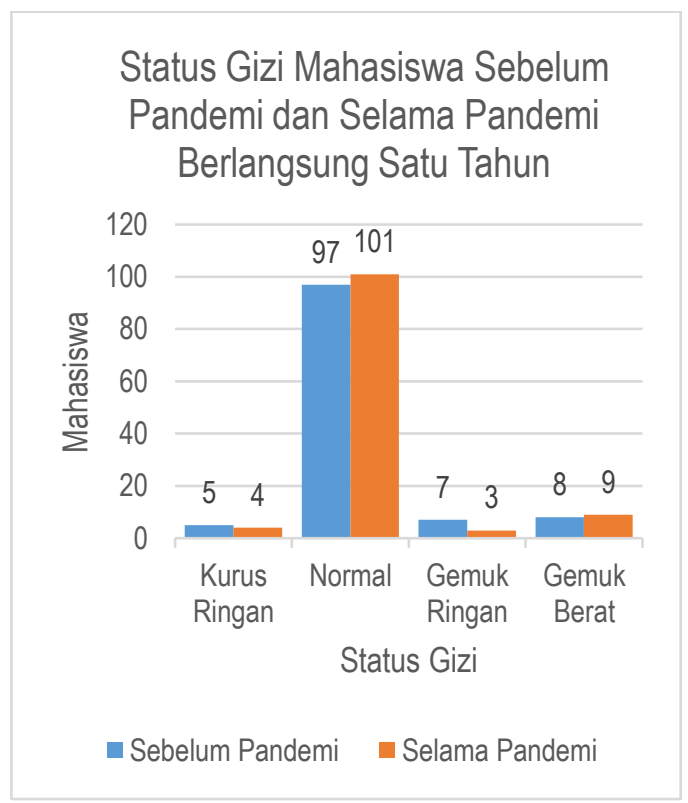

Gambar 2. Grafik Status Gizi

Gambar 1 menunjukkan persebaran kategori tingkat aktivitas fisik, dimana terdapat 112 subjek mengalami penurunan dan hanya 1 subjek mengalami peningkatan aktivitas fisik selama pandemi. Gambar 2 menunjukkan persebaran kategori status gizi 
subjek sebelum dan selama pandemi berlangsung. Terdapat 54 subjek mengalami peningkatan IMT dan 18 subjek mengalami penurunan IMT.

\section{PEMBAHASAN}

Berdasarkan hasil penelitian didapatkan perbedaan yang signifikan pada semua variabel, baik aktivitas fisik dan IMT antara keadaan sebelum pandemi dan selama pandemi berlangsung satu tahun. Hasil penelitian menunjukkan aktivitas fisik subjek menurun secara signifikan dengan rata-rata penurunan sebanyak 1734.70 METsmenit/minggu. Hal ini dimungkinkan karena kegiatan perkuliahan selama pandemi dilakukan secara daring, sehingga mahasiswa cenderung menghabiskan waktu hanya duduk di depan layar. Meski beberapa mata kuliah praktik mengharuskan mahasiswa untuk tetap bergerak, namun gerakan atau latihan yang dilakukan tetap tidak optimal karena terbatasnya sarana dan prasarana.

Berbeda ketika sebelum pandemi Covid-19, perkuliahan yang dilakukan secara luring mengharuskan mahasiswa untuk terus aktif bergerak, bahkan ketika berpindah ruang perkuliahan atau berpindah lapangan ketika kuliah praktik. Secara tidak langsung, mobilitas mahasiswa saat perkuliahan luring jauh lebih tinggi. Terlebih dalam satu hari paling tidak terdapat dua mata kuliah praktik yang menuntut mahasiswa untuk melakukan aktivitas fisik dengan intensitas tinggi. Sebagian besar mahasiswa olahraga juga diketahui dalam unit kegiatan mahasiswa (UKM) berbagai cabang olahraga, selama pandemi seluruh kegiatan mahasiswa secara luring dinonaktifkan sehingga mahasiswa tidak dapat lagi aktif untuk melakukan latihan. Meski demikian, penting untuk diketahui bahwa selama kondisi pandemi, kesehatan harus menjadi perhatian utama agar imunitas tubuh selalu terjaga.

Aktivitas fisik dan olahraga secara positif terkait dengan hasil yang menguntungkan pada metabolisme (diabetes, obesitas, dan sindrom metabolik) dan imunologi (tingkat aktivasi kekebalan tubuh, keefektifan vaksin, penurunan kekebalan tubuh) (Wong et al., 2019). Diketahui olahraga yang dilakukan secara teratur meningkatkan respon imun terhadap antigen mikroba pada manusia (Zheng et al., 2015). Dimana aktivitas fisik yang baik dilakukan saat pandemi untuk menjaga imunitas tubuh adalah aktivitas fisik dengan intensitas ringan hingga sedang (Luzi \& Radaelli, 2020). Olahraga dengan intensitas sedang meningkatkan sistem imun, tetapi intensitas yang berat dapat menghambatnya, terutama pada orang dengan perilaku sedenter (Jiménez- 
Arifah Kaharina, Idzam Kholid Akbar, Oce Wiriawan \& Hari Setijono | Penurunan Aktivitas Fisik dan Peningkatan Status Gizi Selama Pandemi Covid-19 Pada Mahasiswa Olahraga

Pavón et al., 2020).Hal serupa diungkapkan oleh Codella et al., (2015), olahraga intensitas tinggi atau berkepanjangan (seperti lari maraton) dapat menurunkan respon imun, terutama karena peningkatan kortisol endogen.

Variabel IMT mengalami peningkatan yang signifikan dengan rata-rata peningkatan pada berat badan sebanyak $0.78 \mathrm{~kg}$. Hal ini dimungkinkan karena konsumsi makan mahasiswa masih dalam porsi yang tetap, namun aktivitas fisiknya cendurung jauh menurun. Meski pola makan dengan konsumsi makanan yang beragam baik untuk kesehatan terutama ketika masa pandemi, namun jika tidak diimbangi dengan aktivitas fisik yang sesuai, dalam jangka waktu tertentu dapat meningkatkan akumulasi lemak sehingga risiko obesitas dan menjadi awal dari penyebab penyakit tidak menular.

Dalam studi meta-analisis pada anak dan remaja oleh Korczak et al., (2017), disebutkan dampak negatif dari penurunan kesehatan fisik diantaranya hilangnya kebugaran otot dan kardiorespirasi serta penambahan berat badan. Peningkatan berat badan juga dilaporkan oleh Maltoni et al., (2021), aturan lockdown berkontribusi terhadap perubahan berat badan pada remaja dengan obesitas. Data diambil sebelum dan setelah diberlakukan lockdown selama 40 hari. Dimana terjadi peningkatan berat badan rata-rata $3.8 \mathrm{~kg}$ pada laki-laki dan $1.2 \mathrm{~kg}$ pada perempuan.

Peningkatan perilaku sedenter rata-rata 2.9 jam/hari dan penurunan aktivitas fisik rata-rata 1 jam/minggu. Hal ini perlu perhatian khusus agar tidak terjadi peningkatan berat badan yang lebih besar jika aturan physical distancing berlangsung dalam jangka waktu yang lebih lama lagi. Maka kemungkinan risiko obesitas akan semakin besar. Penderita obesitas lebih rentan untuk terpapar Covid-19 dan menunjukkan tingkat keparahan yang lebih serius saat terpapar. Obesitas menjadi komorbitas yang sangat umum pada kasus Covid-19 yang parah pada anak-anak dan remaja. Pada infeksi coronavirus sindrom pernapasan akut yang parah, perubahan organik dari obesitas dapat meningkatkan kebutuhan akan bantuan ventilasi, risiko tromboemboli, penurunan laju filtrasi glomerulus, perubahan respons imun bawaan dan adaptif, serta kelangsungan respons inflamasi kronis.

Dalam studi review klinis, Nogueira-de-Almeida et al., (2020) menyimpulkan berbagai faktor yang meningkatkan risiko obesitas karena aturan pembatasan sosial diantaranya stres, gangguan tidur, perilaku sedenter, makanan siap saji dan penggunaan makanan olahan ultra, minimnya paparan sinar matahari sehingga menurunkan kadar 
vitamin $\mathrm{D}$, lebih banyak waktu didepan layar, dan kenaikan konsumsi minuman dengan kadar pemanis yang tinggi.

Physical distancing menuntut perubahan drastis pada aktivitas dalam kehidupan sehari-hari. Perubahan pola aktivitas fisik yang terjadi adalah penurunan aktivitas fisik dan peningkatan perilaku sedenter subjek. Apabila perilaku ini berlangsung terus-menerus, dikhawatirkan akan berdampak pada meningkatnya risiko obesitas bahkan penyakit tidak menular. Hal ini perlu mendapat perhatian, sehingga upaya pencegahan dapat dilakukan.

\section{SIMPULAN}

Dapat disimpulkan aturan physical distancing yang berlangsung selama satu tahun berdampak pada penurunan aktivitas fisik dan peningkatan IMT secara signifikan pada mahasiswa olahraga. Sebelum pandemi rata-rata subjek melakukan aktivitas fisik dengan kategori berat, namun selama pandemi subjek melakukan aktivitas fisik dengan kategori sedang. Diperlukan pemahaman untuk tetap mempertahankan status gizi normal dan derajat kebugaran jasmani optimal dengan mengatur pola makan dan melakukan aktivitas fisik yang terukur. Diperlukan penelitian lanjutan sebagai pemantauan kesehatan fisik dan mental, serta intervensi pola aktivitas fisik yang tepat selama pandemi dengan karakteristik subjek yang beragam dan skala yang lebih luas.

\section{REFERENSI}

Codella, R., Luzi, L., Inverardi, L., \& Ricordi, C. (2015). The anti-inflammatory effects of exercise in the syndromic thread of diabetes and autoimmunity. Diambil 20 Juli 2021, dari European Review for Medical and Pharmacological Sciences website: https://pubmed.ncbi.nlm.nih.gov/26502862/

Fogelholm, M., Malmberg, J., Suni, J., Santtila, M., Kyröläinen, H., Mäntysaari, M., \& Oja, P. (2006). International Physical Activity Questionnaire. https://doi.org/10.1249/01.mss.0000194075.16960.20

Haapala, E. A., Väistö, J., Lintu, N., Westgate, K., Ekelund, U., Poikkeus, A. M., ... Lakka, T. A. (2017). Physical activity and sedentary time in relation to academic achievement in children. Journal of Science and Medicine in Sport, 20(6), 583-589. https://doi.org/10.1016/j.jsams.2016.11.003

Jiménez-Pavón, D., Carbonell-Baeza, A., \& Lavie, C. J. (2020). Physical exercise as therapy to fight against the mental and physical consequences of COVID-19 quarantine: Special focus in older people. Progress in Cardiovascular Diseases, 63(3), 386-388. https://doi.org/10.1016/j.pcad.2020.03.009 
Arifah Kaharina, Idzam Kholid Akbar, Oce Wiriawan \& Hari Setijono | Penurunan Aktivitas Fisik dan Peningkatan Status Gizi Selama Pandemi Covid-19 Pada Mahasiswa Olahraga

Kemenkes RI. (2018). Klasifikasi Obesitas setelah pengukuran IMT - Direktorat P2PTM. Diambil 26 Juli 2021, dari 07 November 2018 website: http://p2ptm.kemkes.go.id/infographic-p2ptm/obesitas/klasifikasi-obesitas-setelahpengukuran-imt

Korczak, D. J., Madigan, S., \& Colasanto, M. (2017). Children's physical activity and depression: A meta-analysis. Pediatrics, 139(4). https://doi.org/10.1542/peds.20162266

Luzi, L., \& Radaelli, M. G. (2020). Influenza and obesity: its odd relationship and the lessons for COVID-19 pandemic. Acta Diabetologica, 57(6), 759-764. https://doi.org/10.1007/s00592-020-01522-8

Maltoni, G., Zioutas, M., Deiana, G., Biserni, G. B., Pession, A., \& Zucchini, S. (2021). Gender differences in weight gain during lockdown due to COVID-19 pandemic in adolescents with obesity. Nutrition, Metabolism and Cardiovascular Diseases, 31(7), 2181-2185. https://doi.org/10.1016/j.numecd.2021.03.018

Nogueira-de-Almeida, C. A., Del Ciampo, L. A., Ferraz, I. S., Del Ciampo, I. R. L., Contini, A. A., \& Ued, F. da V. (2020). COVID-19 and obesity in childhood and adolescence: a clinical review. Jornal de Pediatria, 96(5), 546-558. https://doi.org/10.1016/j.jped.2020.07.001

Organization, W. H. (2010). Global recommendations on physical activity for health. Diambil 19 Juli 2021, dari Geneva: World Health Organization website: http://medcontent.metapress.com/index/A65RM03P4874243N.pdf\%5Cnhttp://scholar .google.com/scholar?hl=en\&btnG=Search\&q=intitle:Global+Recomendations+on+phy sical+activity+for+health\#0

Rojali, W. I., Ngadiman, Budi, D. R., Nurcahyo, P. J., \& Febriani, A. R. (2021). Evaluasi Pembelajaran Daring Mata Pelajaran Pendidikan Jasmani Olahraga dan Kesehatan SMA Pada Era Pandemi Covid-19. Jurnal MensSana, 6(1), 92-99.

Sugiyono. (2019). Metode Penelitian Kuantitatif, Kualitatif, dan R\&D. Bandung: Alfabeta.

UNESCO. (2020). UNESCO rallies international organizations, civil society and private sector partners in a broad Coalition to ensure \#LearningNeverStops. Diambil 19 Juli 2021, dari Unesco website: https://en.unesco.org/news/unesco-rallies-internationalorganizations-civil-society-and-private-sector-partners-broad

Wong, G. C. L., Narang, V., Lu, Y., Camous, X., Nyunt, M. S. Z., Carre, C., ... Larbi, A. (2019). Hallmarks of improved immunological responses in the vaccination of more physically active elderly females. Diambil 20 Juli 2021, dari Exercise immunology review website: https://www.researchgate.net/publication/331595375_Hallmarks_of_improved_immu nological_responses_in_the_vaccination_of_more_physically_active_elderly_females 
Zheng, Q., Cui, G., Chen, J., Gao, H., Wei, Y., Uede, T., ... Diao, H. (2015). Regular Exercise Enhances the Immune Response Against Microbial Antigens Through UpRegulation of Toll-like Receptor Signaling Pathways. Cellular Physiology and Biochemistry, 37(2), 735-746. https://doi.org/10.1159/000430391 